\title{
Effect of food supplementation on the growth of an intertidal scavenger
}

\author{
Stephen C. McKillup*, Ruth V. McKillup \\ Department of Biology, Central Queensland University, Rockhampton, Queensland 4702, Australia
}

\begin{abstract}
A manipulative field experiment was done to examine the effect of additional carrion on the growth and reproduction of the intertidal scavenging snail Nassarius dorsatus Röding at Coorooman Creek, Central Queensland, Australia. Separate from the manipulation, samples were taken monthly for 3 yr to determine the pattern of growth of $N$. dorsatus. Carrion was supplemented by offering chopped fish to snails in 3 pools for 1 h every 2 to $4 \mathrm{~d}$ for 3 mo; snails in 3 control pools were not offered additional carrion. $N$. dorsatus appeared to recruit throughout the year, grow rapidly and die withun 2 mo after setflement, which is an extremely short life cycle compared with nassariids from higher latitudes. There was no significant difference in the mean size of $N$. dorsatus between treatments before supplementation and those $5 \mathrm{wk}$ after it had ceased. During supplementation, snails in the experimental treatment were significantly larger and marked juveniles grew significantly faster than those in the control. It is suggested that the scavenging fauna of intertidal sandflats and mudflats may have a considerable capacity to absorb carrion and that bioturbation caused by increased densities of burrowing scavengers may affect the structure of soft sediment communities.
\end{abstract}

KEY WORDS: Food Growth Intertidal Scavenger Shortage Supplementation

\section{INTRODUCTION}

Scavengers are species which feed either wholly or partly on the carcasses of other animals they have not killed themselves, and thus obtain a highly concentrated source of animal protem without the cost of attacking or killing live prey (Heinrich 1988). Nevertheless, the availability of carrion may be temporally and spatially unpredictable; a particular carcass is only available for a limited time before it is eaten or decays (Houston 1979) and a scavenger cannot control the conversion of living animals to carcasses (Andrewartha \& Birch 1984). Consequently, although scavengers may experience times when carrion is abundant, they may also experience unpredictable episodes of shortage (Houston 1979). As nitrogen rich food is important for the growth and reproduction of many animals (White 1978, 1993) the supply of carrion may be an important constraint on growth and reproduction of both obligate and facultative scavengers.

·E-mail:s.mckillup@cqu.edu.au
Carrion may be especially infrequent and unpredicatable in the deep sea (e.g. Dayton \& Hessler 1972) and thus it has been suggested that relatively large and mobile species which can range widely are likely to be obligate scavengers, but smaller species may be generalists (Jumars \& Gallagher 1982). More recently, however, Britton \& Morton (1994) have argued that almost all marine scavengers, apart perhaps from some nassariid gastropods and lysianassid amphipods, are facultative rather than obligate consumers of carrion.

Scavenging invertebrates, especially decapod crustaceans and gastropod molluscs, are often common on sheltered intertidal sandflats and mudflats (e.g. Scheltema 1964, Cernohorsky 1972). Indirect evidence suggests that intertidal scavengers, including several species of nassariid gastropods, may be short of food in the field (e.g. Curtis \& Hurd 1979, McKillup \& Butler 1979, Britton \& Morton 1993, 1994, McKillup \& McKillup $1994 \mathrm{a}, \mathrm{b}, 1995)$. If so, their growth and reproduction should be enhanced by food supplementation, but we can find only 1 test of this: in an unreplicated experiment, Fusaro (1978) found the proportion of ovigerous 
females of the mole crab Hippa pacifica increased significantly at a food supplemented site compared with an unmanipulated control.

We report on the population characteristics of the intertidal scavenger Nassarius dorsatus and the effects of supplementing carrion available to this species for 3 mo in the field.

\section{MATERIALS AND METHODS}

Species and study site. Nassarius dorsatus is common at the mid-tide level on sheltered intertidal mudflats in the Indo West Pacific (Short \& Potter 1987) and abundant on a large (approximately $4 \mathrm{~km}^{2}$ ) mudflat at the mouth of Coorooman Creek, Central Queensland, Australia $\left(23^{\circ} 18^{\prime} \mathrm{S}, 150^{\circ} 45^{\prime} \mathrm{E}\right)$.

Nassarius dorsatus emerges from the substratum as soon as the tide has receded but reburies before being covered by the rising tide (McKillup \& McKillup 1994b) and does not emerge from the substrate while submersed during high tide, even if carrion is present (McKillup \& McKillup unpubl.). The Coorooman Creek mudflat does not drain completely at low tide; shallow pools up to $4 \mathrm{~cm}$ deep remain which are separated from others by higher and firmer substratum. N. dorsatus are common within these pools, few are found in the firmer substratum; snails do not crawl out of pools at low tide (McKillup \& McKillup 1994b) and marked individuals were only ever recovered from the pools within which they were placed (McKillup \& McKillup unpubl.). Consequently it was possible to repeatedly sample snails from a particular pool and supplement carrion within discrete pools on the mudflat.

Population characteristics of Nassarius dorsatus. At least 50 and usually $100 \mathrm{~N}$. dorsatus from the same $100 \mathrm{~m}^{2}$ pool. $300 \mathrm{~m}$ west of the southern side of the mouth of Coorooman Creek (Fig. 1), were measured every month from January 1993 to December 1995. Snails were collected by searching the substratum by hand to a depth of $4 \mathrm{~cm}$ in randomly chosen $15 \mathrm{~cm}$ wide strips, their shell length measured to the nearest mm. classified as either juvenile or adult (the latter had a varix on the shell) and returned to their pool within 15 min.

Experimental manipulation of food availability. Six pools (each about $50 \mathrm{~m}^{2}$ ) at the same tidal height were chosen at random. All contained Nassarius dorsatus and were at least $30 \mathrm{~m}$ from a neighbouring pool (Fig 1). Three were assigned at random to a 'food supplemented' experimental treatment. Blue threadfin salmon Eleutheronema tetradactylus fillets (ca $200 \mathrm{~g}$ ) chopped into $2 \times 2 \times 1 \mathrm{~cm}$ pieces (ca 60 per pool), each piece secured to the substratum by a $25 \mathrm{~cm}$ bamboo skewer, were placed in each pool for $1 \mathrm{~h}$ after which any remaining was removed. Food was supplemented

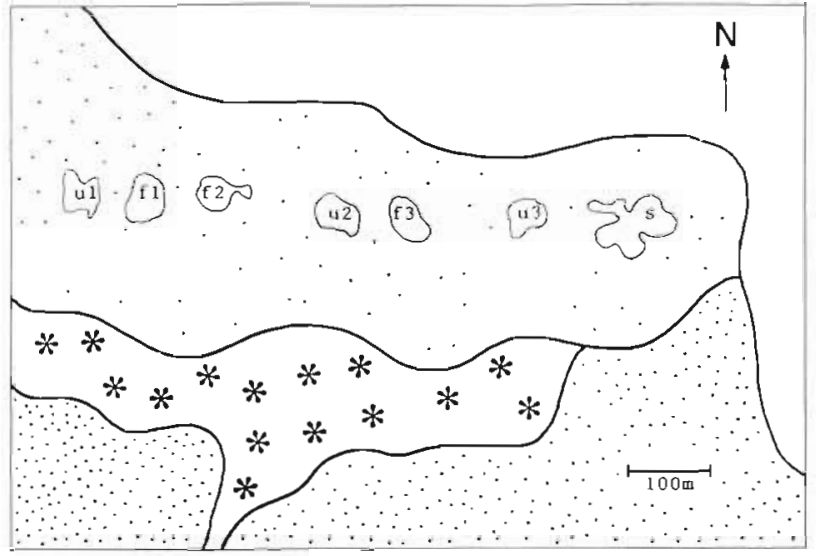

Fig. 1. Coorooman Creek, Central Queensland, Australia. s location of the pool sampled every month for $3 \mathrm{yr} ; \mathrm{f} 1, \mathrm{f} 2$ and $\mathrm{f} 3$ the 3 pools in which food was supplemented; $u 1, u 2$ and $u 3$ : the 3 unmanipulated controls. Light stippling: mudflat; tree symbols: mangrove swamp; dense stippling: salt marsh

every 2 to $4 \mathrm{~d}$ on 38 occasions from 22 August 1995 to 22 November 1995. Snails in 3 control pools were not given additional food.

On 21 August 1995, 1 day before supplemental feeding began, 50 snails from each replicate of both treatments were collected, classified as juvenile or adult, measured and returned to their pools within $15 \mathrm{~min}$. This was subsequently done for 100 snails on 21 September, 19 October, 22 November and 5 wk after supplemental feeding had ceased (26 December 1995), except for 1 pool in which only 50 snails could be found on the last sampling date.

On 21 September 1995, 20 juvenile snails between 10.0 and $10.9 \mathrm{~mm}$ long from each pool were marked by attaching a $1 \mathrm{~mm}^{3}$ ball of quick setting black epoxy putty to the spire of their shell and immediately returned to their pool. It was intended to remeasure these marked snails during the monthly sampling described above, but after finding growth was more rapid than expected (see 'Results') a second group of 20 juvenile snails between 10.0 and $10.9 \mathrm{~mm}$ long from each pool were marked as described previously, but with grey epoxy putty, on 19 October 1995. Every time food was subsequently supplemented all pools were searched for marked snails, which were classified as juvenile or adult and measured to the nearest $\mathrm{mm}$.

\section{RESULTS}

\section{Population characteristics of Nassarius dorsatus}

Fig. 2 shows histograms for the size of Nassarius dorsatus from the $100 \mathrm{~m}^{2}$ pool on the mudflat each month from January 1993 to December 1995. A wide range of 
sizes, including individuals of shell length less than $10 \mathrm{~mm}$, was present in each sample and there was no obvious seasonal pattern of growth. The only time a cohort appeared to grow over several successive months was from February 1994 to May 1994. Adult snails never comprised more than $7 \%$ of a sample

\section{Experimental manipulation of food availability}

The mean size of Nassarius dorsatus for each replicate of both treatments before, during and after supplementation of food in the experimental treatment is shown in Fig. 3. These data were analysed as a 3-factor ANOVA of treatment and time (the latter was treated as a fixed factor because treatment effects were expected to be associated with time in this experiment), with pools as a random factor nested within each treatment. The effects of treatment $\left(F_{1,4}=\right.$ $16.80, \mathrm{p}<0.001)$ and time $\left(F_{4.16}=8.63, \mathrm{p}\right.$ $<0.001)$, together with the interaction between these $\left(F_{4,10}=3.12, \mathrm{p}<0.05\right)$ were significant; there were also significant differences amongst pools nested within each treatment $\left(F_{4,2620}=36.86, \mathrm{p}\right.$ $<0.001$ ) and a significant interaction between time and pools within each treatment $\left(F_{16.2620}=204.51, \mathrm{p}<0.001\right)$. These effects are evident in Fig. 3. Considering the expectation that there would be no difference between treatments before, but a significant difference during, supplementation, the data for each month were then analysed as 5 separate 2-factor ANOVAs with treatment as a fixed factor and pools as a random factor nested within each treatment (Table 1). There was no difference in the size of snails between treatments before and those 5 wk after supplementation, but during supplementation snails from the experimental treatment were significantly larger than those from the control. The $F$-ratio for the nested factor (pools) increased during the experiment and was significant from October onwards. There was no significant difference in the proportion of adult snails between the treatment and control samples on any sampling date (Table 2).

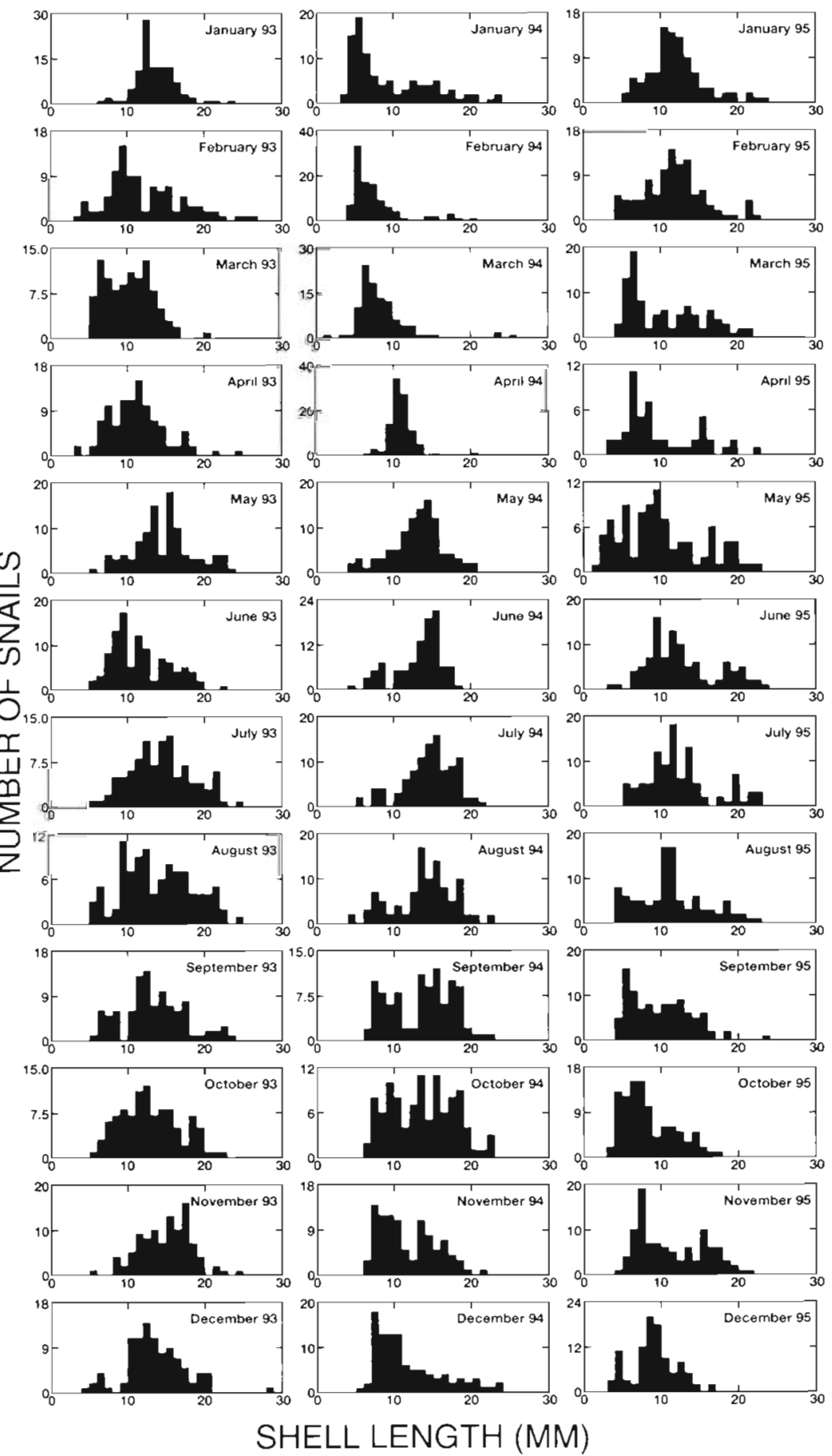

Fig. 2. Nassarius dorsatus. Size frequency histograms at Coorooman Creek sampled every month from January 1993 to December 1995. Scale of the $y$-axis differs amongst graphs

Data for the mean sizes of the second group of marked snails in each treatment are in Fig. 4 and were combined within treatments for each day because few snails were recaptured. The number of marked snails recovered diminished with time from a maximum of 


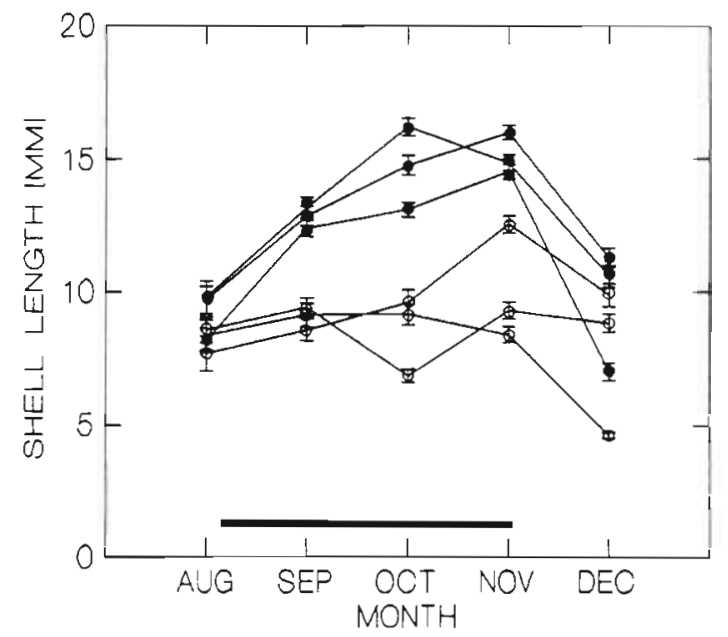

Fig. 3. Nassarius dorsatus. Mean size in each of 3 replicates of experimental and control treatments before (August), during (September to November) and after (December) food was supplemented. Filled symbols: food supplemented pools; open symbols: control pools. Solid horizontal line shows period of food supplementation. Bars show the standard error of each mean

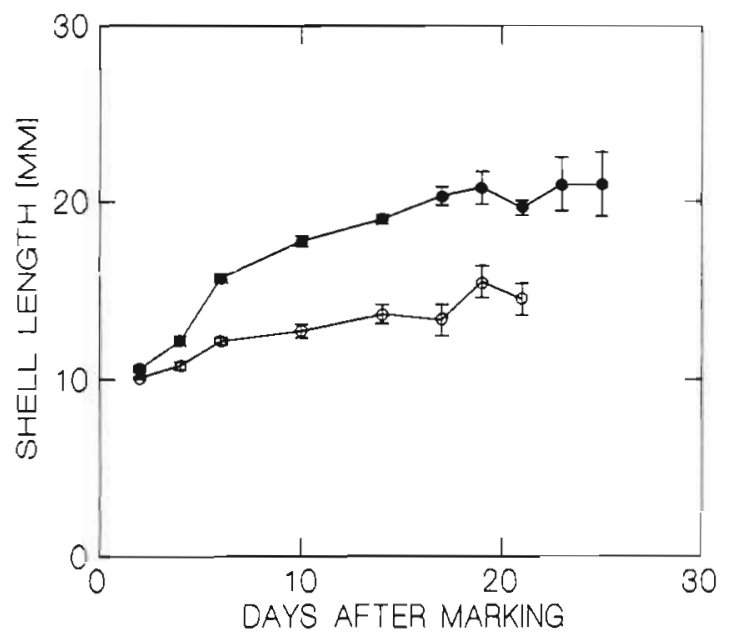

Fig. 4. Nassarius dorsatus. Growth of marked snails in the experimental and control treatment. Data have been combined within each treatment. Filled symbols: food supplemented experimental treatment; open symbols: control. Bars show the standard error of each mean

13 per treatment to 6 or fewer in each from Day 17 onwards); those in the experimental treatment grew significantly faster than those in the control (ANCOVA preliminary analysis for parallelism on log transformed data: interaction $F_{1,120}=28.63, p<0.001$ ). In November, 12 marked shells with a varix (4 live and 8 dead) were found in the experimental treatment, but none with a varix were found in the control. Only dead marked snails were found beyond $25 \mathrm{~d}$ after marking (13 November 1995).
Table 1 Results of separate 2-way ANOVAs with 1 nested factor in the shell length data for each month before (August). during (September to November) and after (December) food was supplemented on the mudflat. The pools(treatment) sum of squares has been used as the denominator to obtain the F-ratio for the treatment comparison. ns: $p>0.05$

\begin{tabular}{|c|c|c|c|c|c|}
\hline Source & SS & $\mathrm{df}$ & MS & $F$ & $\mathrm{p}$ \\
\hline \multicolumn{6}{|c|}{ August (before supplementation) } \\
\hline Treatment & 94.10 & 1 & 94.10 & 3.50 & ns \\
\hline Pools(Treatment) & 107.41 & 4 & 26.85 & 1.56 & ns \\
\hline Error & 5050.92 & 294 & 17.18 & & \\
\hline \multicolumn{6}{|l|}{ September } \\
\hline Treatment & 2511.22 & 1 & 2511.22 & 74.75 & $<0.01$ \\
\hline Pools(Treatment) & 134.38 & 4 & 33.59 & 1.77 & ns \\
\hline Error & 11262.24 & 594 & 18.96 & & \\
\hline \multicolumn{6}{|l|}{ October } \\
\hline Treatment & 6619.76 & 1 & 6619.76 & 20.34 & $<0.01$ \\
\hline Pools(Treatment) & 1301.94 & 4 & 325.49 & 22.87 & $<0.01$ \\
\hline Error & 8452.62 & 594 & 14.23 & & \\
\hline \multicolumn{6}{|l|}{ November } \\
\hline Treatment & 5236.47 & 1 & 5236.47 & 12.24 & $<0.05$ \\
\hline Pools(Treatment) & 1711.27 & 4 & 427.82 & 37.41 & $<0.01$ \\
\hline Error & 6792.36 & 594 & 11.44 & & \\
\hline \multicolumn{6}{|c|}{ December (after supplementation) } \\
\hline Treatment & 482.43 & 1 & 482.43 & 0.71 & ns \\
\hline Pools(Treatment) & 2734.94 & 4 & 683.74 & 49.17 & $<0.01$ \\
\hline Error & 7567.04 & 544 & 13.91 & & \\
\hline
\end{tabular}

Table 2. Numbers of adult and juvenile snails in each treatment before (August), during (September to November) and after (December) food was supplemented. Fisher exact probabilities are for $2 \times 2$ contingency table comparisons of the proportion of adults between treatments for each month

\begin{tabular}{|lccccc|}
\hline Month & \multicolumn{2}{c}{$\begin{array}{c}\text { Control } \\
\text { Juvenile }\end{array}$} & \multicolumn{2}{c|}{$\begin{array}{c}\text { Experimental } \\
\text { Juvenile }\end{array}$} & $\begin{array}{c}\text { Fisher } \\
\text { exact }\end{array}$ \\
\hline August & 146 & 4 & 147 & 3 & 1.00 \\
September & 295 & 5 & 291 & 9 & 0.418 \\
October & 297 & 3 & 293 & 7 & 0.340 \\
November & 297 & 3 & 293 & 7 & 0.340 \\
December & 299 & 1 & 245 & 5 & 0.097 \\
\hline
\end{tabular}

\section{DISCUSSION}

Data for the monthly sampling of Nassarius dorsatus at Coorooman Creek, together with results of the feeding experiment, suggest this species recruits frequently and is surprisingly short lived. A range of sizes was present in each monthly sample and there was no evidence of annual recruitment or growth of a particular cohort for more than a few months. Marked $10 \mathrm{~mm}$ long $N$. dorsatus grew by up to $8 \mathrm{~mm}$ during the next $10 \mathrm{~d}$, after which the rate of growth decreased and snails died within a month even if they did not reach sexual maturity. Assuming the growth of snails smaller 
than $10 \mathrm{~mm}$ in the field is also rapid, $N$. dorsatus appears to live for only about 2 mo after settlement, during which it grows to a maximum shell length of about $27 \mathrm{~mm}$. This growth pattern has also been observed for $3 \mathrm{~mm}$ long $N$ dorsatus collected from Coorooman Creek and reared in the laboratory from September to November at room temperature (26 to $34^{\circ} \mathrm{C}$ ) with ad libitum food (McKillup \& McKillup unpubl.) We can find no other reports of the growth rates of tropical nassariids, but Nassarius pauperatus from $35^{\circ} \mathrm{S}$ reproduces annually and becomes sexually mature after growing up to $19 \mathrm{~mm}$ in the first $15 \mathrm{mo}$ after settlement. (McKillup 1979) while $N$. reticulatus from $58^{\circ} \mathrm{N}$ also reproduces annually, lives for up to $15 \mathrm{yr}$ and becomes sexually mature after growing approximately $15 \mathrm{~mm}$ during the first 4 yr after settlement (Tallmark 1980). Molluscan growth rates often vary with temperature and latitude (e.g. Ansell 1968, Beukema \& Meehan 1985) and have been reported to be relatively rapid in the tropics (e.g. Ansell et al. 1972, although see Frank 1969).

A short life cycle and rapid growth that is limited by the availability of food can explain the significant size difference between snails in the control and experimental treatments of the feeding experiment only 1 mo after supplementation began, as well as the lack of a significant difference $5 \mathrm{wk}$ after supplementation ceased. Thus, this experiment has shown that availability of carrion significantly affects the growth of Nassarius dorsatus at Coorooman Creek. Furthermore, some marked snails survived to sexual maturity in the experimental treatment, but no mature marked individuals were ever found in the control. Unmarked mature snails were found in both treatments, however, but the proportion in each was low and did not differ significantly between them, which may have been because carrion was only supplemented for $1 \mathrm{~h}$ every 2 to $4 \mathrm{~d}$ in the experimental pools. More frequent and prolonged supplementation may have resulted in an even greater rate of growth and survival to sexual maturity; in this context Fusaro (1978) found that the proportion of ovigerous females of the mole crab Hippa pacifica increased significantly at a site where food was supplemented daily.

Perhaps most importantly, the results suggest that most Nassarius dorsatus at Coorooman Creek did not obtain sufficient carrion to survive to maturity. There are at least 2 explanations for this: the experiment may have been done when food was, by chance, relatively scarce, or it may always be relatively scarce at Coorooman Creek. The second possibility appears more likely considering the feeding behaviour of $N$. dorsatus at this site on several different occasions (McKillup \& McKillup 1994b). Food availability has also been found to vary amongst populations of $N$. pauperatus; at sites where the sandflat is wide and gently sloping, recruitment density is relatively high and food for adults is in short supply, while at sites where the sandflat is less extensive, recruitment density is relatively lower and more food is available for adults (McKillup 1979 McKillup \& Butler 1979, 1983, McKillup et al. 1993). N. pauperatus has a planktotrophic larval stage so recruitment at a particular site does not necessarily rely upon reproduction at that site; some populations appear to be 'sinks' (where mortality may exceed natality) while others are 'sources' (where natality may exceed mortality) (Dias 1996). It is not known whether such differences occur among populations of N. dorsatus.

Since the feeding experiment was only done at 1 site, the results cannot necessarily be generalised to all populations of Nassarius dorsatus, nor to other species of intertidal scavengers. If, however, intertidal scavengers are commonly short of food, growth rates of individuals and the density of natural populations may increase in response to food supplementation. The capacity of the scavenging fauna of intertidal sandflats and mudflats to absorb additional carrion may be considerable, and supplementation of the food of intertidal scavengers may, in turn, affect the growth and survival of species which prey on them.

Finally, an increase in the amount of carrion available to burrowing scavengers may have additional effects on the structure of soft sediment communities because burrowing animals physically disturb the substratum (e.g. Woodin 1978, DeWitt \& Levington 1985 , Warwick et al. 1990). Since many marine habitats are becoming increasingly polluted with carrion from discarded by-catch (e.g. Wassenberg \& Hill 1987, Britton \& Morton 1994) such indirect effects of anthropogenic supplementation may already be occurring on many shores.

Acknowledgements. We thank Alan Butler, Mike Coates and 2 anonymous referees for ther comments on the manuscript. The research was supported by a university research grant and 1 semester of study leave from the Faculty of Applied Science, Central Queensland University

\section{LITERATURE CITED}

Andrewartha HG, Birch LC (1984) The ecological web. University of Chicago Press, Chicago

Ansell AD (1968) The rate of growth of the hard clam Mercenaria mercenaria (L.) throughout the geographical range. J Cons Int Explor Mer 31:364-409

Ansell AD, Sivadas P, Narayanan B, Trevallion A (1972) The ecology of two sandy beaches in south west India. III. Observations on the population of Donax incarnatus and D. spiculum. Mar Biol 17:318-332

Beukema JJ, Meehan BW (1985) Latitudinal variation in linear growth and other shell characterustics of Macoma balthica. Mar Brol 90:27-33 
Britton JC, Morton B (1993) Marine invertebrate scavengers. In: Morton B (ed) The marine biology of the South China Sca. Proceedings of the International Conference on the Marme Biology of Hong Kong and the South ( hina Sea, Hong Kong. Hong Kong University Press, Hong Kong, p $357-391$

Britton JC, Morton B (1994) Marine carrion and scavengers. Oceanogr Mar Biol Annu Rev 32:369-434

Cernohorsky WO (1972) Indo-Pacific Nassarildae (Mollusca: Gastropoda). Rec Auck Inst Mus 9:125-1.94

Curtis LA, Hurd LE (1979) On the broad nutritional requirements of the mud snail, Myanassa (Nassarius) obsoleta (Say), and its polytrophic role in the food web. J Exp Mar Biol Ecol 41:289-297

Dayton PK, Hessler RR (1972) Role of biological disturbance in maintalning diversity in the deep sea. Deep Sea Res 1.9: 199-208

DeWitt TH, Levinton JS (1985) Disturbance, emigration, and refugia: how the mud snail, Ilyanassa obsoleta (Say). affects the habitat distribution of an epifaunal amphipod, Microdeutopus gryllotalpa (Costa). J Exp Mar Biol Ecol 92: $97-113$

Dias PC (1996) Sources and sinks in population ecology. Trends Ecol Evol 11:326-330

Frank PW (1969) Growth rates and longevily of some gastropod mollusks on the coral reef at Herron Island. Oecologia $2: 232-250$

Fusaro C (1978) Food availability and egg production: a field experiment with Hippa pacifica Dana (Decapoda; Hippidae). Pacif Sci 32:17-23

Heinnch B (1988) Winter foraging at carcasses by 3 sympatric corvids, with emphasis on recruitment by the raven. Corvus corax. Behav Ecol Sociobiol 23:141-156

Houston DC (1979) The adaptations of scavengers. In: Sinclair ARE, Norton-Griffiths $M$ (eds) Serengeti. Dynamics of an ecosystem. The University of Chicago Press, Chicago, p $261-286$

Jumars PA, Gallagher ED (1982) Deep-sea community structure: 3 plays on the benthic proscenium. In: Ernst $W G$, Morin JG (eds) The environment of the deep sea. PrenticeHall, Englewood Cliffs, NJ, p 217-255

McKillup SC (1979) Behavıoural differences between populations of Nassarius pauperatus (Mollusca: Prosobranchia).

This article was presented by $R$. N. Hughes (Senior Editorial Advisor), Bangor, UK
PhD thesis, University of Adelaide, South Australia

Mckillup SC, Butler AJ (1979) Modification of egg production and packaging in response to food avallabulity by Nassarus pauperatus. Oecologia 43:221-231

Mckillup SC, Butler AJ (1983) The measurnment of hunger as a relative estımate of food avallable to populations of $\mathrm{Nas}$ sarius pauperatus. Oecologia 56:16-22

McKillup SC, Butler AJ, McKillup RV (1993) The importance of sandflat morphology to recruitment of the intertidal snail Nassarius pauperatus during ten consecutive years at three sites in South Australia. Mar Biol 115:577-580

Mckillup SC, McKillup RV (1994a) Reproduction and growth of the smooth pebble crab Philyra laevis (Bell 1885) at two sites in South Australia during 1990-91. Trans R Soc S Aust 118:245-251

McKillup SC, McKillup RV (1994b) The decision to feed by a scavenger in relation to the risks of predation and starvation. Oecologia 97:41.-48

Mckillup SC, McKillup RV (1995) The responses of intertidal scavengers to damaged conspecifics in the field. Mar Fresh Behav Physiol 27:49-57

Scheltema RS (1964) Feeding habits and growth in the mudsnail Nassarius obsoletus. Chesapeake Sci 5:161-166

Short JW, Potter DG (1987) Shells of Queensland and the Great Barrier Reef. Robert Brown and Associates, Bathurst, NSW

Talimark B (1980) Population dynamics of Nassarius reticulatus (Gastropoda, Prosobranchia) in Gullmar Fjord, Sweden. Mar Ecol Prog Ser 3:51-62

Warwlck RM, Clarke KR, Gee JM (1990) The effects of disturbance by soldier crabs Mictyris platycheles $H$. Milne Edwards on meiobenthic community structure. J Exp Mar Biol Ecol 135:19-33

Wassenberg TJ, Hill BJ (1987) Feeding by the sand crab Portunus pelagicus on material discarded from prawn trawlers in Moreton Bay, Australia. Mar Biol 95:387-393

White TCR (1978) The importance of a relative shortage of food in animal ecology. Oecologia 33:71-86

White TCR (1993) The inadequate environment. Nitrogen and the abundance of animals. Springer-Verlag, Berlin

Woodin SA (1978) Refuges, disturbance, and community structure: a marine soft-bottom example. Ecology 59: $274-284$

Manuscript first received: August 9, 1996

Revised version accepted: January 8, 1997 